\title{
Saludo A Las Mujeres Trabajadoras
}

Con orgullo y entusiasmo, con semillas de amistad

Conocí a mujeres del mundo entero, que nos ayudan a soñar.

Son las mujeres de WiEgo que nos instan a,

Sembrar ilusiones de justicia social

No te hinques de rodillas, no te pongas a llorar,

Une tu mano a mi mano que la lucha hay que globalizar

Une tu mano a mi mano y para defender nuestra dignidad

Une tu voz a la mía, para gritar al mundo entero el valor de la igualdad

Unamos las manos, unamos las voces, para romper el silencio, de la

invisibilidad

Con palabras e ideas, con firmeza, con valor. Las mujeres trabajadoras por los derechos humanos levantamos nuestra voz.

Somos las invisibilizadas del mundo entero, que nos atrevemos a soñar con unidad y solidaridad, para cambiar este modelo, que nos impide avanzar.

A ti mujer consiente te quiero saludar

\section{Greeting to All Working Women}

With pride and enthusiasm, and seeds of friendship I met women from all over the world, who help us dream.

These are women in WIEGO who urge us to,

Sow illusions of social justice

Do not kneel down, do not cry,

Join your hand to mine, as the struggle we must globalize

Join your hand to mine, to defend our dignity and

Join your voice to mine, so that we can shout to the whole world the

value of equality

Let us join hands, let us join voices, to break the silence, of invisibility

With words and ideas, with strength and courage.

Women working for human rights must raise our voice.

We are the ones who are invisible in the world, who dare to dream of

unity and solidarity,

to change this model, which prevents us from moving forth.

It is you concious woman, to whom I want to salute. 
Malin Nilsson, Indrani Mazumdar, and Silke Neunsinger - 9789004499614 Downloaded from Brill.come4/26/2023 02:46:32PM via free access 